\title{
Coagulation, Microenvironment and Liver Fibrosis
}

\author{
Niccolò Bitto ${ }^{1}$, Eleonora Liguori ${ }^{1}$ and Vincenzo La Mura ${ }^{2,3,4, * \text { (B) }}$ \\ 1 Medicina Interna, Istituto di Ricovero e Cura a Carattere Scientifico (IRCCS) San Donato, \\ Università Degli Studi di Milano, 20097 San Donato Milanese (MI), Italy; nicobitto@gmail.com (N.B.); \\ eleonora.liguori1982@gmail.com (E.L.) \\ 2 Fondazione IRCCS Ca' Granda, Ospedale Maggiore Policlinico, \\ UOC Medicina Generale-Emostasi e Trombosi, 20122 Milano, Italy \\ 3 Dipartimento di Scienze biomediche per la Salute, Università degli Studi di Milano, 20122 Milano, Italy \\ 4 A. M. and A. Migliavacca per lo studio delle Malattie del Fegato, 20122 Milano, Italy \\ * Correspondence: vincenzo.lamura@unimi.it; Tel.: +39-02-5503-5430
}

Received: 10 June 2018; Accepted: 20 July 2018; Published: 24 July 2018

\begin{abstract}
Fibrosis is the main consequence of any kind of chronic liver damage. Coagulation and thrombin generation are crucial in the physiological response to tissue injury; however, the inappropriate and uncontrolled activation of coagulation cascade may lead to fibrosis development due to the involvement of several cellular types and biochemical pathways in response to thrombin generation. In the liver, hepatic stellate cells and sinusoidal endothelial cells orchestrate fibrogenic response to chronic damage. Thrombin interacts with these cytotypes mainly through protease-activated receptors (PARs), which are expressed by endothelium, platelets and hepatic stellate cells. This review focuses on the impact of coagulation in liver fibrogenesis, describes receptors and pathways involved and explores the potential antifibrotic properties of drugs active in hemostasis in studies with cells, animal models of liver damage and humans.
\end{abstract}

Keywords: thrombin; protease-activated receptors; endothelial dysfunction; von Willebrand factor; hepatitis; cirrhosis; anticoagulation

\section{Introduction}

Fibrogenesis is a complex biochemical process that represents the hallmark of damage for the most common chronic diseases of the liver. The activation of hepatic stellate cells (HSC) is the key pathogenic mechanism for the initiation, progression, and regression of liver fibrosis. Several studies have gone into more depth on the complex and tightly regulated cross talk at the level of hepatic microcirculation owing to sinusoidal endothelial cells (SEC), Kuppfer cells (KC), and hepatocytes with HSC. This underlines the participation of several hepatic cellular types in fibrogenesis. Our manuscript offers an overview on the pathogenic role played by coagulation and thrombin generation in this complex cellular cross talk by considering fibrosis a wound healing process secondary to micro-thrombi in small hepatic and portal venules, sinusoidal ischemic injury and hepatocyte injury. In addition, thrombin may participate in fibrogenesis by interaction with HSC via protease-activated receptors (PAR-1 and PAR-4), promoting a myo-fibroblast phenotype, fibronectin fibril assembly, and may act as a chemoattractant for inflammatory cells. Altogether, these observations suggest that drugs interfering with the coagulation process have potential as antifibrotic drugs at any stage of chronic liver disease. The in vitro and in vivo studies on these aspects are the main focus of the review. 


\section{Coagulation in Fibrosis and Disease Progression}

\subsection{Hepatic Stellate Cells, Endothelium and Fibrosis: Role of PARs}

During coagulation, the conversion of fibrinogen into fibrin is a key reaction catalyzed by thrombin, a serine protease which is generated on the surface of activated platelets in response to vascular or tissue injury [1]. Thrombin generation is a tightly regulated process, as it is the expression of the delicate balance between pro-coagulant and anti-coagulant factors. Besides its hemostatic function, thrombin orchestrates cell recruitment in response to any kind of tissue injury and activates endothelium [2-4]. Its interaction with inflammatory and mesenchymal cells is part of the wound healing process, in which hemostasis precedes and initiates tissue repair by fibrin deposition [5]. In 1991, the discovery of protease activated receptors (PARs) clarified the biological pathway of thrombin [6]. PARs are a family of receptors with proteolytic activity, which mediate thrombin (PAR 1, 3, 4)- or tryptase (PAR 2, 4)-induced cellular response. PARs are G-protein-coupled receptors and are activated by irreversible proteolytic cleavage of their $\mathrm{N}$-terminal domain. They are expressed by several cellular types involved in fine regulation of vascular homeostasis and their signaling pathways are complex, as they are potentially coupled to G-proteins with different functions (Figure 1). As a result, they interact with a plethora of signaling transducers (e.g., Rho/Rho-kinase, c-Jun N terminal kinase, IP3, PI3K, JAK-STAT), with consequent pleiotropic effects [7,8]. Endothelium (via PAR1, PAR2) and platelets (PAR1, 4), are the main cells involved in the regulation of vasomotor function and hemostasis exerted by PARs [9]. At low concentrations, thrombin may induce a barrier protective response by endothelium, this effect is mediated by PAR-1 [10]. On the contrary, at high concentrations, thrombin induces a pro-inflammatory, pro-hemostatic and contracting phenotype of endothelium, as it increases the expression of TF, plasminogen activator inhibitor-1 expression (PAI-1), pro-inflammatory cytokines (IL6, IL8) and endothelin-1, among others [7]. This bi-modal effect of thrombin suggests that a disrupted regulation of thrombin generation, as occurs in pro-coagulant conditions, may overcome its physiological interaction with the endothelium and may induce significant tissue injury. Alongside endothelium, platelets are activated by PAR-1 and PAR-4, and inhibition of these receptors is a potent anti-platelet mechanism, confirming the important role played by these receptors on platelet function [11,12]. Thrombin is produced on the surface of activated platelets and its interaction with PARs may initiate and maintain the hemostatic process, leading to thrombus formation when anticoagulant factors are not able to counterbalance this process $[1,7]$. In recent years, the transcription factor Kruppel-like factor 2 (KFL2) has been recognized as a key regulator of endothelium homeostasis in response to inflammatory stimuli (e.g., tumor necrosis factor, $\mathrm{TNF} \alpha$, and interleukin 1) and hemodynamic forces like laminar shear stress [13,14]. Interestingly, Marrone et al. demonstrated that KLF2 overexpression in SEC and HSC proceeding from cirrhotic rats reduces HSC activation and ameliorates paracrine cross-talk with SEC [15,16]. This is in line with the reduction of fibrosis and portal pressure observed in animal studies in association with KFL2 expression [17]. In 2005, Li et al. demonstrated that KLF2 induction blunts the pro-inflammatory, pro-hemostatic transcriptional response of the endothelium exposed to noxious stimuli (e.g., TNF $\alpha$ ), as it reduces tissue factor, Von Willebrand Factor (VWF) and PAI-1 [18]. Interestingly, ADAMTS-13, a metalloproteinase which regulates the pro-hemostatic function of VWF by its cleavage, is produced by HSC in physiological conditions and its activity declines alongside liver dysfunction [19,20]. Absolute deficiency of ADAMTS-13 leads to diffuse microvascular occlusion due to high molecular weight VWF multimers which promote platelet aggregation and microthrombi formation; therefore, low levels of ADAMTS-13 are of increasing interest in thrombotic-microangiopathies and those clinical conditions like sepsis in which liver failure, as well as other organ dysfunctions are frequently observed [21,22]. All these observations emphasize the role of HSCs-SEC interaction to maintain an anti-thrombotic phenotype at sinusoidal level in physiology, with a potential protective role of KFL2 due to its control of VWF and platelet aggregation. Moreover, KFL2 may also have a direct role in the direct control of hemostasis by the endothelium, since it inhibits PAR-1 expression on endothelial cells. This shows 
a direct link between KLF-2-induced regulation of endothelial physiology and the biological response of this cytotype to thrombin. Whereas in vascular medicine studies on PARs focus on platelets and endothelium, PARs expression by HSCs is central in liver fibrogenesis [17]. The progression of any chronic liver disease is characterized by the acquisition of a contractile and pro-fibrogenic phenotype by HSCs, along with an imbalance between vasoconstrictors and vasodilators produced by SECs. As a consequence, the liver parenchyma is distorted by the development of interstitial fibrosis and the constriction of sinusoids which, in turn, lead to the increase of portal pressure owing to the mechanical and functional increase of liver resistance to the portal blood flow [23]. Several studies have explored thrombin-PARs interaction on HSC in the process of liver fibrogenesis. They are summarized in Table 1. The action of thrombin on PARs (mainly PAR-1) induces fibrogenic response in the liver by reprogramming HSCs with the induction of a pro-fibrotic, activated phenotype [24-26]. Incremental doses of thrombin progressively transform HSCs into myofibroblasts, with increase of $\alpha \mathrm{SMA}$, pro-collagen, TGF $\beta-1$ and other key cellular signals which are crucial in the wound healing response [24]. The uncontrolled persistence of a thrombin-related signaling through PARs, due to a pro-hemostatic milieu, is considered the main mechanism that binds hemostasis and fibrosis [27]. In line with this theory, experimental inhibition of PARs prevents the fibrogenic response of HSCs and the progression of fibrosis as demonstrated in pre-clinical studies with animal models of liver disease and cell cultures $[26,28]$. In addition to PAR-1, PAR-2 showed similar pro-fibrotic effects by inducing HSC contraction, collagen production and MMP-2 expression, this last promoting liver fibrosis due to extracellular matrix remodeling [25,29-31]. Furthermore, studies with PAR $^{-/-}$transgenic mice confirmed the importance of this receptor in several models of liver fibrosis (xenobiotics, carbon-tetrachloride, $\mathrm{CCL}_{4}$, and thioacetamide, TAA) [30,32,33] and, recently, even in a model fatty liver disease [34]. To our knowledge, just one study explored PAR-1 genotype and liver fibrosis in patients with chronic HCV infection. In this biopsy-proven study, a particular PAR-1 polymorphism $(1426 \mathrm{C} / \mathrm{T})$ correlated with increased liver fibrosis, thus confirming the above-mentioned results from pre-clinical studies [35]. Alongside PARs, tissue factor (TF) has been often investigated in liver fibrosis, since TF is a potent activator of hemostasis via factor VII (FVII) [36]. Interestingly, transgenic mice lacking of TF show a reduced rate of fibrosis development after exposure to various chronic damage stimuli, thus confirming a potential connection between the pro-hemostatic role of TF and liver fibrosis [31,34]. Recently, Ratou et al., in a study with mice after bile duct ligation (an animal model of liver fibrosis), demonstrated an increase of thrombin-antithrombin complexes, which are biomarkers of a pro-coagulant condition. This increase was prevented in mice lacking in TF. However, this anti-coagulant phenotype was not associated with a significant reduction of fibrosis [37], in contrast to other studies [30]. 
Table 1. Studies exploring the impact of coagulation on liver fibrosis.

\begin{tabular}{|c|c|c|c|c|}
\hline Reference & Experimental Model & Pathway Explored & Methods & Results \\
\hline Chambers 1998 [24] & human fetal lung fibroblasts & PAR-1 & $\begin{array}{l}\text { Exposure to incremental dose of thrombin; TRAPs } \\
\text { (thrombin receptor-activating peptide) }+/ \text { - inhibitors } \\
\text { (hirudin/Phe-Pro-ArgCH2CL) }\end{array}$ & $\begin{array}{l}\text { Thrombin } \uparrow \alpha \text { I-procollagen mRNA through PAR-1 } \\
\text { activation }\end{array}$ \\
\hline Gaça 2002 [25] & Cultured stellate HSEC & Thrombin, tryptase/PAR 1-2 & $\begin{array}{l}\text { PAR } 1 / 2 \text { mRNA RT-PCR analysis + northern blotting in } \\
\text { lysate of HSEC. Use of PD98059 (kinase inhibitor) }\end{array}$ & $\begin{array}{l}\uparrow \text { PAR- } 1 / 2 \text { while fibroblast transforms in myofibroblast } \\
\text { phenotype } \\
\uparrow \text { HSC proliferation by PARs }\end{array}$ \\
\hline Fiorucci et al. 2004 [26] & rat HSC cell line; BDL cirrhotic rat & Thrombin-PAR & $\begin{array}{l}\text { type I collagen mRNA expression; quantitative } \\
\text { morphometric analysis; hepatic and urinary excretion of } \\
\text { hydroxyproline }\end{array}$ & $\begin{array}{l}\text { Thrombin triggers HSC activation and collagen deposition } \\
\text { via PARs, prevented by PAR } \text { antagonist }^{\text {ant }}\end{array}$ \\
\hline $\begin{array}{l}\text { J Gillibert Duplantier et al. } \\
\qquad 2007[38]\end{array}$ & Human hepatic myofibroblasts & $\begin{array}{l}\text { PAR-1; COX-2; Akt-1; platelet } \\
\text { derived growth factor (PDGF) }\end{array}$ & $\begin{array}{l}\text { Cell migration; RNA isolation and analysis for } \\
\text { Prostaglandin E2 receptor; analysis of Akt-1 } \\
\text { phosphorylation and PDGF-receptor phosphorylation. }\end{array}$ & $\begin{array}{l}\text { Thrombin inhibits human hepatic myofibroblast migration } \\
\text { via PAR-1; } \\
\text { Thrombin inhibits PDGF induced migration (inhibition } \\
\text { of PI3K) }\end{array}$ \\
\hline Martinelli 2007 [35] & Patients with HCV (287 european, 90 brazilian) & PAR1 & $\begin{array}{l}\text { Cross-sectional study; fibrosis evaluated by liver biopsy; } \\
\text { polymorphism of PAR-1 gene analysis ( }-1426 \text { C/T, IVS-14, } \\
-506 \text { I/D }\end{array}$ & $\uparrow$ fibrosis in TT genotype of $1426 \mathrm{C} / \mathrm{T}$ polymorphism \\
\hline Rullier 2008 [32] & PAR-1 ${ }^{-/-}$and $+/-$mice exposed to $\mathrm{CCL}_{4}$ & PAR1 & $\begin{array}{l}\text { Histology; RT-PCR for type I collagen, MMP-2, PDGF } \beta-\text { r, } \\
\text { MP-1, mRNA }\end{array}$ & $\begin{array}{l}\downarrow \text { fibrosis and activated fibrogenic cells } \\
\downarrow \text { type I collagen, MMP-2, PDGF } \beta-\mathrm{r} \text { mRNA } \\
\downarrow \mathrm{T} \text { lymphoctyes infiltration }\end{array}$ \\
\hline B. P. Sullivan et al. 2010 [33] & $\begin{array}{c}\text { Bile duct epithelial cells (BDECs); PAR1 } 1^{-/-} \text {, } \\
\text { TF }+/- \text {, mice with low levels of human TF } \\
\text { expression. All mice were fed with BDEC } \\
\text { toxicant (ANIT); Human Liver Samples from } \\
\text { patients with PBC/PSC }\end{array}$ & TF, PAR-1, $\alpha \vee \beta 6$ & $\begin{array}{l}\text { Real-Time PCR of snap-frozen liver } \\
\text { or adherent cells; immunofluorescence on liver frozen } \\
\text { sections for } \alpha \mathrm{V} \beta 6\end{array}$ & $\begin{array}{l}\text { TF and PAR-1 deficiency } \downarrow \text { Liver Fibrosis } / \alpha V \beta 6 \text { mRNA } \\
\uparrow \text { TGF- } \beta 1 \text { related } \alpha \mathrm{V} \beta 6 \text { expression by PAR- } 1 \\
\alpha V \beta 6 \text { inhibition } \downarrow \text { fibrosis } \\
\uparrow \text { TF and PAR- } 1 \text { mRNAs in livers from PBC/PSC patients }\end{array}$ \\
\hline V. Knight et al. 2012 [31] & 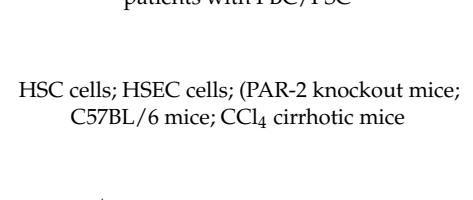 & PARs & $\begin{array}{l}\text { Hepatic hydroxyproline content in frozen liver tissue; PCR } \\
\text { analysis of MMP-2, TIMP-1 and PAR-1/2; identification of } \\
\alpha \text {-SMA, F4/80 and CD } 68 \text {; TGF- } \beta 1 \text { Production In Vitro; HSC } \\
\text { Proliferation in Response to PAR Activation; Hepatic } \\
\text { TGF- } \beta 1 \text { Content }\end{array}$ & $\begin{array}{l}\text { PAR-2 Deficiency } \downarrow \text { Fibrosis / procollagen } \\
\text { mRNA//Hydroxyproline } \\
\text { Content/ } \\
\text { Stellate Cell Activation/ } \\
\text { Hepatic TGF- } \beta 1 \text { Expression/MMPs/ Activated Hepatic } \\
\text { Macrophages; } \\
\text { PAR } 1 / 2 \uparrow \text { HSC Collagen Production/TGF- } \beta 1\end{array}$ \\
\hline R. Nault et al. 2016 [34] & $\begin{array}{l}\text { PAR-1 }-/- \text { and }+/- \text { mice exposed to to TCDD } \\
\text { (progression to NASH) }\end{array}$ & PAR-1; & Identification of Fibrin(ogen) & $\begin{array}{l}\text { TCDD Exposure Activates the Coagulation Cascade; } \\
\downarrow \text { inflammation and collagen deposition in PAR-1 }-1-\end{array}$ \\
\hline V. Knight et al. 2017 [30] & $\begin{array}{l}\text { PAR-1-1- mice; } \\
\text { HSC cells; } \\
\mathrm{CCl}_{4} \text { treated mice }\end{array}$ & TF and PARs & $\begin{array}{l}\text { Hepatic fibrosis assessment; Hepatic collagen content; Gene } \\
\text { expression of TGF- } \beta 1 \text {, MMP-2, TIMP 1, PAR1 and 2; } \\
\text { expression TGF- } \beta 1\end{array}$ & $\downarrow_{-/-}$fibrosis/MMP2/activated macrophages in TF and PAR-1 \\
\hline
\end{tabular}


In summary, hemostasis may drive a pro-fibrotic HSC phenotype via PARs. The cellular cross talk between HSCs and SECs and the expression of KLF2 may somehow reduce the fibrogenic process associated with a pro-coagulant imbalance under chronic conditions of liver damage.

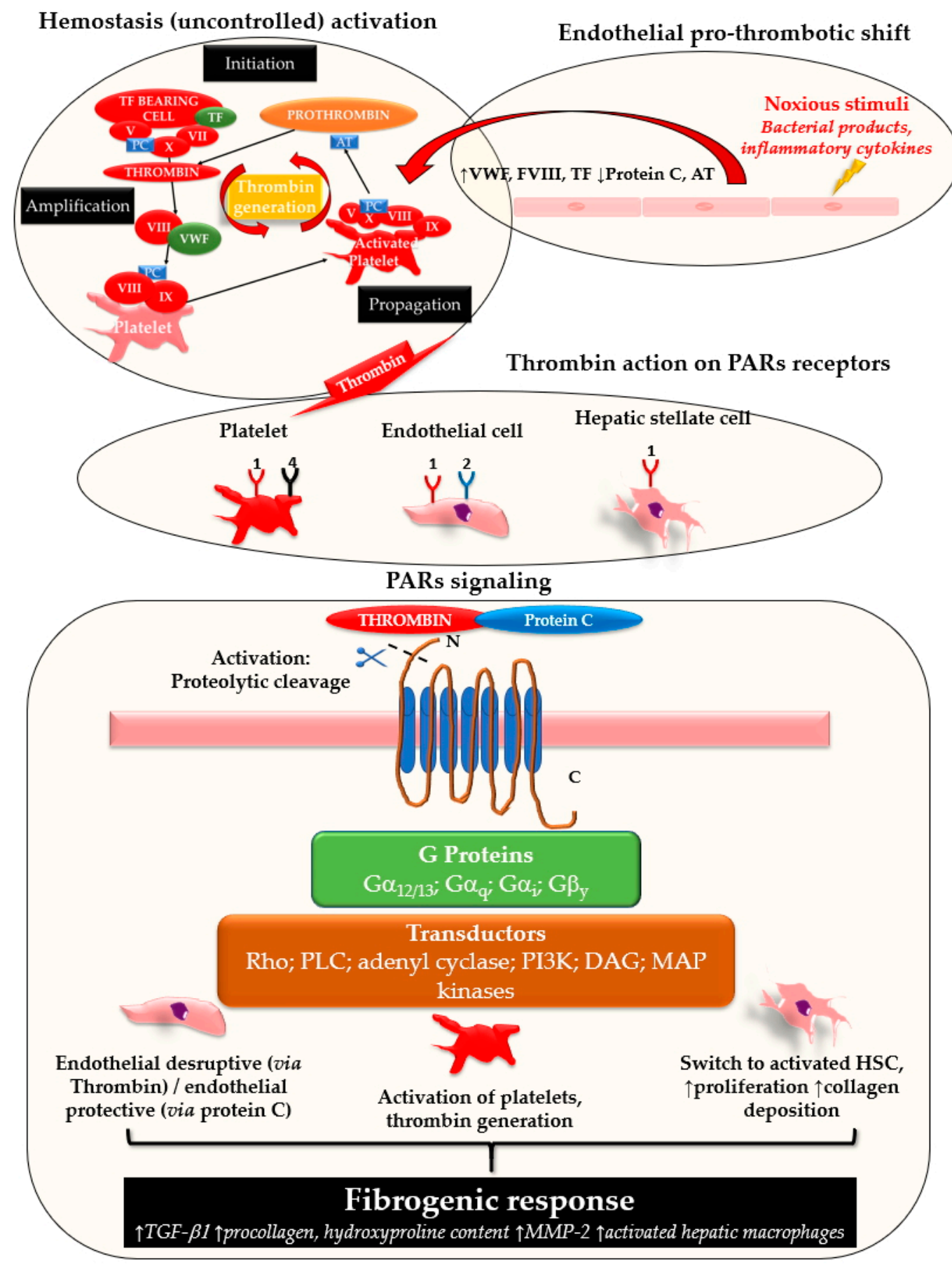

Figure 1. Schematic representation of PAR signaling.

\subsection{Parenchymal Extinction: From Clot Generation to Liver Damage}

An important step in the knowledge of coagulation as a mechanism of liver damage was the study by Wanless et al., who conducted a histological analysis by comparing 61 cirrhotic livers of any etiology removed at the time of transplantation with 24 livers from autopsy of normal subjects as controls [39]. The main purpose of the study was to confirm the previous observation that fibrosis 
co-localizes with vascular lesions of the hepatic venous system [40]. First, they distinguished origin (hepatic or portal), caliber (small, medium or large) and size (\% of luminal narrowing) of vascular lesions. Second, they graded fibrosis with description by optical microscope and defined focal parenchymal extinction as a region of parenchymal loss filled by fibrosis. Hepatic and portal vein intimal fibrosis, highly suggestive of previous occlusion, were respectively evident in $70 \%$ and $36 \%$ of livers. In morphometric data on 534 hepatic veins pooled from 10 livers, hepatic vein occlusions were frequent in small veins and co-localized with a greater extent of fibrosis. The existence of a "post thrombotic syndrome" was also inferred by patchy distribution of fibrotic areas, multiple layers of fibrosis and the severe occlusion of the smallest veins. In another study, the same group analyzed 13 autopsy livers with congestive fibrosis, with another 12 livers as controls [41]. In this model, venous stasis was associated with thrombosis of sinusoids and terminal hepatic venules, with formation of fibrotic septa and sinusoidal fibrotic thickening. These changes were associated with the extension of thrombosis to larger veins, necrosis and parenchymal loss. Recently, Simonetto et al. confirmed these results in an animal model of congestive hepatopathy (partial inferior vena cava ligation), showing hepatic sinusoidal thrombosis with increase of liver stiffness and portal pressure [42]. Interestingly, fibrosis was accompanied by minimal inflammation, whereas mechanical forces seemed to prevail with stretch-induced fibronectin-fibrils assembly. Of note, tissue factor pathway inhibitor or warfarin treatment blunted sinusoidal thrombosis and fibrosis deposition, confirming the existence of a hemostasis-driven fibrogenesis in this model of liver congestion. They also analyzed liver specimens of patients with congenital heart failure due to chronic myocardial dysfunction or Fontan cardiac surgery, which is a set of surgical techniques causing venous hypertension after deriving the systemic venous flow directly into the pulmonary artery. In these patients, immunochemistry analysis revealed fibrin deposition within sinusoids, confirming the association between microthrombosis and fibrosis. The lack of inflammation in this study is apparently in line with the pre-clinical study by Cerini et al. who demonstrated a minimal anti-inflammatory effect of heparin, alongside a potent anti-fibrotic impact prevalently due to the anticoagulant properties of the drug. These results are in line with a recent work by Miyao et al., who demonstrated in a mice model of non-alcoholic fatty liver disease that sinusoidal endothelial injury may precede the activation of Kupffer cells, HSC, inflammation and fibrosis [43]. Therefore, despite inflammation being a cardinal element in development of a biological response to every kind of noxious stimuli, its link with hemostasis probably cannot explain alone the consequent fibrogenic response. Recent evidence, elsewhere reviewed by De Ridder et al. [44], focuses on the precise site of thrombin generation, identified in the intravascular or the interstitial anatomical space. Whereas intravascular activation is easily understood and studied in micro and macrovascular medicine, thrombin activity in the interstitial space is intriguing and often neglected [44]. However, liver fibrosis is, by definition, an interstitial process, and it is conceivable that thrombin exerts an important and complex action on fibrogenic response, for example by activating pro- [45] and anti-fibrotic [46]. metalloproteinases present in the extracellular matrix. The exact link, if it exists, between the intravascular and interstitial generation of thrombin during chronic hepatitis is certainly an open question, which is even more of interest for hepatologists, as recent studies have shown that anti-coagulation per se may favorably impact the natural history of cirrhosis [47,48].

In conclusion, parenchymal extinction theory represents the bridge between pre-clinical studies demonstrating a role of hemostasis on liver fibrogenesis and the pathological observations of liver parenchymal loss due to vascular occlusion, progressive necrosis and fibrosis replacement in humans. However, as thrombin explains its action also in the interstitium, further studies are warranted to confirm and define precisely the weight of microvascular and interstitial changes due to the activation of thrombin as consequence of a chronic liver damage. 


\subsection{Procoagulant Imbalance and Disease Progression: Clinical Observations}

\subsubsection{Common Inherited Pro-Hemostatic Genotype and Risk of Fibrosis Development}

Unprovoked venous-thromboembolic events are often linked with pro-hemostatic mutations of clotting factors. FV Leiden and FII G20210 mutations are associated with thrombotic events in the general population, with relative common frequency $(0.4-5 \%$ and $3 \%$, respectively) [49-51]. FV Leiden missense mutation (ArG506Gln) leads to an intrinsic resistance to the anticoagulant action of protein C, whereas FII G20210 increases prothrombin levels and inhibits fibrinolysis by the reduction of the thrombin-activatable-fibrinolysis-inhibitor [52,53]. The potential impact on fibrosis development of a constitutional pro-thrombotic imbalance has been hypothesized and explored by several authors. In 2003 Wright et al. conducted a retrospective, biopsy-proven study aimed to describe the degree of association between the most common thrombophilic factors and the severity of liver fibrosis. In this study, FV Leiden, but not FII G20210 mutation was associated with accelerated fibrosis and cirrhosis development in patients with HCV infection [54]. In contrast, Maharshak et al. demonstrated an association between faster fibrosis and FII G20210 mutation with no evidence for FV Leiden [55]. These divergent results resemble subsequent data showing a potential [54-58] or doubtful impact of thrombophilia on the risk of liver fibrosis development $[57,59,60]$. A recent retrospective population study on 1055 patients demonstrated an association between FV Leiden and FII G20210 mutation and a significant increase in liver stiffness, which is a widely used non-invasive marker of liver fibrosis [56]. Moreover, in this study, non-0 blood group showed the highest liver stiffness in patients with pro-hemostatic mutations. These data are in line with a previous observation of an association of non-0 blood group and fibrosis severity in HCV-infected patients [61,62]. Interestingly, AB0 blood group is a major determinant of VWF and factor VIII (FVIII) levels in normal subjects, both potent pro-hemostatic factors, and non-0 blood group has been associated with increased levels of VWF and FVIII with increased risk of venous-thrombo-embolism [63,64]. In summary, a pro-hemostatic genotype may have a role in the development of fibrosis. However, evidence is limited to observational studies. The clinical question if thrombophilic inherited mutations may identify clusters of patients with high risk of fibrosis progression is appealing. Thus, it advocates proof of concept studies to clarify the impact and the magnitude of these mutations on fibrosis development.

\subsubsection{Hemostatic Balance in Advanced Liver Disease}

Every stage of liver disease results in a different degree of change in the hemostatic balance [65]. For years, the alteration of conventional coagulation tests (e.g., prothrombin time, partial activated thromboplastin time, bleeding time) disguised the coagulopathy of liver disease under a bleeding mask, represented by the assumption of spontaneous bleeding among patients with cirrhosis, the final grade of any chronic liver disease [66]. This is true in terms of spontaneous gastro-intestinal bleeding, but today we know that this is a consequence of portal hypertension and not of a disease-related reduction of plasma activating the coagulation cascade [48,67]. Indeed, in cirrhosis, the reduction of liver-dependent pro-hemostatic clotting factors (FII, V, VII, IX, X and XI) is counterbalanced by the reduction of anticoagulant factors and similar contrasting alterations in the fibrinolytic system [65]. As a result, the evaluation of the plasmatic hemostatic balance by the in vitro thrombin generation test, which takes into account both pro- and anti-coagulant factors, showed normal thrombin generation in these patients [68]. Therefore, the first seminal study by Tripodi et al. [68] allowed a shift from the old paradigm of an intrinsic bleeding tendency, to the concept of "re-balanced hemostasis" in patients with chronic liver disease $[69,70]$. Moreover, the same research group demonstrated a resistance to the action of thrombomodulin, a strong anticoagulant, which parallels disease severity and a progressive pro-coagulant imbalance of clotting factors [71,72]. The hypothesis of a pro-coagulant plasmatic milieu in cirrhosis is intriguing, as thrombotic events are common in this population [73]. Thrombosis of portal and splanchnic venous vessels ranges from 5 to $20 \%$, and the highest rate is observed in the advanced stages of the disease [74,75]. Moreover, retrospective studies have shown that cirrhosis may 
represent a risk factor for venous-thrombo-embolic events in hospitalized patients [76-78]. The increase in FVIII, VWF and the resistance to the action of thrombomodulin due to protein C reduction are the best-described pro-hemostatic features, and worsen along with disease severity $[72,79,80]$. Interestingly, they were all independently associated with increased portal hypertension and worse prognosis, suggesting a potential impact on the pathogenesis of this clinical condition [81-85]. However, the design of these studies does not allow the uncovering of a cause-effect relationship between fibrosis and pro-hemostatic changes, despite an interesting role for VWF as a noninvasive marker of fibrosis in two studies $[86,87]$. Nevertheless, a potential impact of coagulation on fibrogenesis and parenchymal extinction is fascinating and is currently under investigation by several research groups. One potential limitation is the lack of a study investigating hemostasis in liver disease far from advanced stages or cirrhosis. Recently, two distinct leading groups in this field have published contrasting evidence on this topic in the clinical setting of non-alcoholic liver disease, which is expected to be the main increasing etiology of cirrhosis in next few years [88-91]. The recent debate that has risen on this topic $[92,93]$ demonstrates the need of further investigations on the impact of hemostasis even in the earliest stages of any chronic disease of the liver.

\section{Anticoagulation as Anti-Fibrotic Strategy}

\subsection{Heparin}

In the era of etiological therapies, which will hopefully erase the burden of chronic viral hepatitis [94], powerful antifibrotic drugs are still lacking $[95,96]$. However, the increasing incidence of metabolic liver disease calls on such therapies, while etiologic treatments for NAFLD/NASH are not yet satisfactory [90]. Several studies have explored antifibrotic proprieties of drugs active on hemostasis (Table 2). Low molecular weight heparins (LMWH) inhibit factor $\mathrm{X}$ indirectly via antithrombin, thus lowering thrombin generation [97]. In a histological study in rats exposed to carbon-tetrachloride $\left(\mathrm{CCL}_{4}\right)$, LMWH reduced fibrosis and collagen deposition, while ultrastructural analysis on transmission electron microscope (TEM) showed reduced sinusoidal swelling and less distorted parenchymal architecture [98]. Dalteparin also showed fibrosis reduction in $\mathrm{CCL}_{4}$ chronic damage, while increasing hepatic-growth factor and blunting pro-fibrotic expression of TGF- $\beta 1$ and deactivating HSC ( $\alpha$ SMA reduction). Interestingly, no effect on necrosis and inflammation was observed, with unchanged levels of TNF [99]. These results were confirmed in a study by Cerini et al., who explored enoxaparin in different rat-models of liver damage: $\mathrm{CCL}_{4}$ (acute/short/long exposure) and TAA exposure [100]. Fibrosis and pro-fibrogenic stimuli were analyzed with histology, immunochemistry and HSC isolation. Additionally, portal pressure and hepatic vascular resistance were analyzed with isolation and perfusion of the liver. Enoxaparin markedly reduced fibrosis, with anti-fibrotic reprogramming of HSC with $\alpha$ SMA and pro-collagen I reduction. Moreover, it also reduced portal pressure without altering hepatic blood flow, thus reducing hepatic resistance in accordance to ohm's law (pressure $=$ flow $\mathrm{x}$ resistance). These results were confirmed in both $\mathrm{CCL}_{4}$ and TAA damage induction. Indeed, enoxaparin disclosed antifibrotic effects in chronic but not acute liver damage and this occurred without any anti-inflammatory action. Therefore, this solid biological background allows to promote LMWHs as potential antifibrotic strategy. Along these lines, relevant clinical data derive from the trial by Villa et al. [47] who randomized 70 patients with decompensated cirrhosis to receive, or not, enoxaparin in order to prevent de novo portal vein thrombosis. Surprisingly, the treatment arm prevented de novo portal vein thrombosis without any increase of the bleeding rate, and patients showed better clinical outcomes in term of new decompensating events (mainly ascites development) and survival. When treatment was interrupted, both arms turned to similar rates of clinical events and portal vein thrombosis development. This study was the first randomized clinical trial demonstrating the potential impact of anticoagulant on the natural history of cirrhosis, although as of today, no data exist to conclude that the beneficial effect of anticoagulation was mediated by the antifibrotic properties demonstrated in the above-mentioned pre-clinical studies. 
Table 2. Main studies exploring anticoagulant-antifibrotic strategies.

\begin{tabular}{|c|c|c|c|c|c|}
\hline Reference & Drug & Animal Model & $\begin{array}{l}\text { Fibrosis/Cirrhosis } \\
\text { Induction }\end{array}$ & Fibrosis Assesment & Results \\
\hline Duplantier 2004 [28] & Wistars rat & $\begin{array}{l}\text { Thrombin antagonist } \\
\text { SSR182289 }\end{array}$ & $\begin{array}{l}\mathrm{CCL}_{4} \text { (three or seven } \\
\text { week exposure) }\end{array}$ & $\begin{array}{l}\text { Histology; immunohistochemistry (IHC) for } \alpha \text { SMA } \\
\text { collagen type I, MMP-2, TIMP-1, and TIMP-2 } \\
\text { mRNAs by RT-PCR }\end{array}$ & $\begin{array}{l}\downarrow 30 \% \text { fibrosis ( } 7 \text { week } \mathrm{CCL}_{4} \text { exposure) } \\
\text { Early } \downarrow \alpha S M A \text { positive cells/TIMP- } 1 \text { mRNA }\end{array}$ \\
\hline Abe 2007 [99] & Dalteparin & Female Wistars Rats & $\mathrm{CCL}_{4}$ & Histology; IHC & $\begin{array}{l}\downarrow \text { fibrosis, } \uparrow \text { HGF } \\
\downarrow \text { TGF- } \beta 1, \text { COL1A1, } \alpha \text { SMA } \\
\downarrow \text { PDGF induced HSC proliferation }\end{array}$ \\
\hline Anstee 2008 [101] & Warfarin & $\begin{array}{l}\text { FV Leiden mutant mice, } \\
\text { C57BL/ } 6 \text { control animals } \\
\text { anticoagulated mice }\end{array}$ & $\mathrm{CCL}_{4}$ & $\begin{array}{l}\text { Histology; Liver Hidroxiproline content; } \alpha \mathrm{SMA} \\
\text { mRNA expression }\end{array}$ & $\begin{array}{l}\uparrow \text { fibrosis } 80 \% \text { in male } \mathrm{FV} \text { mutant } \\
\text { Warfarin effect: } \\
\downarrow \text { Hidroxiproline content } \downarrow \text { fibrosis scores } \\
\text { Effect blunted in FV mutant }\end{array}$ \\
\hline Kassel 2012 [102] & $\begin{array}{l}\text { Argatroban (via } \\
\text { micro-osmotic pump) }\end{array}$ & $\mathrm{LDLr}^{-/-}$mice & Western diet & $\begin{array}{l}\text { Histology); real time PCR hepatic mRNA expression } \\
\text { of } \alpha \text { SMA, COL1A1, PDGFF, TIMP1/2, TGF- } \beta 1 \text {; } \\
\text { IHC (anti CD } 68, \text { F4/80, } \alpha \text { SMA); MCP-1 Elisa }\end{array}$ & $\begin{array}{l}\text { No change in collagen deposition } \\
\downarrow \alpha \text { SMA, COL1A1, PDGF } \beta, \text { TIMP1/2 } \\
\text { No } \downarrow \text { TGF- } \beta 1 \\
\downarrow \text { inflammation ( } \downarrow \text { neutrophil/macrophage accumulation) }\end{array}$ \\
\hline Cerini 2016 [100] & Enoxaparin & Male Wistars Rats & $\begin{array}{l}\mathrm{CCL}_{4} \text { (acute vs short vs } \\
\text { long term exposure); TAA }\end{array}$ & $\begin{array}{l}\text { Histology; IHC (anti FBN/ } \alpha \mathrm{SMA} / \mathrm{CD} 68) \\
\text { expression of procollagen I/ } \alpha \mathrm{SMA} \text { on isolated } \mathrm{HSC}\end{array}$ & $\begin{array}{l}\downarrow 25-26 \% \text { in short and long term } \mathrm{CCL}_{4} \text { exposure; } \downarrow 41 \% \text { in TAA } \\
\downarrow \mathrm{PP} \text { and HVR } \\
\downarrow \alpha \mathrm{SMA} \text {, procollagen I in HSC } \\
\text { No change on inflammation } \\
\text { No } \downarrow \text { in } \mathrm{CCL}_{4}, \downarrow 25 \% \text { TAA }\end{array}$ \\
\hline Vilaseca 2017 [103] & Rivaroxaban & Cirrhotic wistar rats & $\mathrm{CCL}_{4} ; \mathrm{TAA}$ & $\begin{array}{l}\text { Histology; TEM analysis; Liver Hidroxiproline } \\
\text { content; IHC (anti fibrinogen/ } \alpha \text { SMA/CD68) and IF } \\
\text { (anti FBN, anti VWF); real time PCR hepatic mRNA } \\
\text { expression of } \alpha \text { SMA, COL1A1, PDGF } \beta \text {, TIMP1/2, } \\
\text { TGF- } \beta 1 \text {; in vitro thrombin action on HSC }\end{array}$ & $\begin{array}{l}\text { improved sinusoidal } \\
\text { architecture } \\
\downarrow \text { Hidroxiproline content/collagen/fibrin deposition } \\
\downarrow \text { PP and HVR } \\
\downarrow \text { HSC activity of profibrotic genes } \\
\downarrow \text { VWF expression in vasculature } \\
\text { No direct activity on HSC (in vitro studies) }\end{array}$ \\
\hline Li 2017 [98] & $\begin{array}{l}\text { Aspirin (low / high } \\
\text { dose), enoxaparin }\end{array}$ & Sprague-Dawley rats & TAA & Histology (METAVIR score) & $\downarrow$ in all treatment group (> for high dose aspirin) \\
\hline
\end{tabular}




\subsection{Oral Anticoagulants: From Vitamin K Antagonists to Direct Oral Anticoagulants (DOACs)}

Warfarin is an oral anticoagulant which inhibits the production of clotting factors, thus indirectly abolishing thrombin generation [104]. The laboratory testing of INR (a standardized measure derived from prothrombin time) is specifically designed to monitor the anticoagulant effect of vitamin $\mathrm{k}$ antagonists $[105,106]$. In 2008, Anstee et al. studied the effect of warfarin in mice with prothrombotic mutation of FV Leiden exposed to $\mathrm{CCL}_{4}$ [101]. In this animal model, warfarin significantly reduced fibrosis progression and liver hydroxyproline content, while mice carrying FV mutation exhibited fibrosis progression with blunted effect of warfarin. In recent years, DOACs have radically changed management in hemostasis modulation [107]. This class of drugs directly inhibits the action of clotting factors (FX and FII), thus reducing thrombin generation [107]. The oral assumption and the lack of need of laboratory monitoring are progressively prompting the repeal of vit $\mathrm{k}$ antagonists in favor of this class of drugs, which is currently used in various thrombotic diseases [108]. In 2012, Kassel et al. studied the effect of argatroban, a direct inhibitor of FII, in $\mathrm{LDLr}^{-/-}$fed with a western diet [102]. Argatroban reduced hepatic mRNA expression of $\alpha$ SMA, COL1A1, PDGF $\beta$, TIMP1/2, with no effect on TGF- $\beta 1$ or collagen deposition. In this model of metabolic-induced damage, argatroban significantly reduced inflammation and neutrophil accumulation in the liver, globally showing early change to an anti-inflammatory, anti-fibrotic phenotype. In a recent study, Vilaseca et al. treated rats with chronic liver damage induced by $\mathrm{CCL}_{4}$ and TAA with rivaroxaban, an FX direct inhibitor, which reduces thrombin generation [103]. In this study, rivaroxaban reduced portal pressure and hepatic vascular resistance, confirming the amelioration of liver microcirculation. In in vitro experiments on HSC, there was no clear thrombin-related activating effect. Otherwise, rivaroxaban treatment exerted an anti-fibrotic effect on mRNA expression of $\alpha$ SMA, COL1A1, PDGF $\beta$, TIMP1/2 and TGF- $\beta 1$. Moreover, rivaroxaban reduced fibrin deposition and ameliorated sinusoidal architecture, as seen in TEM analysis, thus suggesting a direct effect on microthrombosis.

In summary, preclinical studies suggest a direct anti-fibrotic effect of oral anticoagulants, which ameliorates liver microvascular perfusion, with an anti-fibrotic reprogramming on HSCs and, at last, reduced fibrin and collagen deposition. However, scant data exist on the use of direct oral coagulant in cirrhotic patients, and prescription is currently limited in this population, with few exceptions in patients with compensated disease [109]. Some registry-based studies are exploring the use of DOACs with promising results [110-112]; however, high-quality evidence in the form of clinical trials is eagerly awaited to confirm the safety profile of these drugs and, potentially, their impact on the natural history of the disease.

\section{Future Directions: Hemostasis as Immune Response}

The use of confocal microscopy recently shed a light on mechanisms of cell interactions in sterile or septic injury, due to the in vivo visualization allowed by the instrument $[113,114]$. The study of hepatic microcirculation, by in vivo visualization of sinusoids, confirmed a central role of the liver in the clearance of bacteria, as demonstrated after inoculation of $\mathrm{S}$. aureus in a murine model [115-117]. Kupffer cells first gather in liver sinusoids after bacteria inoculation, and afterwards, neutrophils and platelets assemble and remain in the liver vasculature by VWF secretion and binding [116,118]. The platelet-neutrophil interaction leads to the organized destruction of neutrophils and the release of neutrophil extracellular traps (NETs), which are networks of neutrophil DNA and histones which entrap and kill bacteria gathered in the sinusoids [119]. This organized neutrophil death program is different from necrosis and apoptosis, and has been called NETosis [120]. While it is crucial in innate immune response, its uncontrolled activation may lead to tissue injury, and several experiments have demonstrated colocalization of NETs and subsequent necrosis. Hemostasis directly interact with NETosis by activated platelets and activation of coagulation in the site of the immune response $[118,121,122]$. Moreover, the demonstration of a VWF binding to histones, which precedes the discovery of NETs, suggests a continuum in hemostasis activation and tissue response to bacteria [123]. Therefore, in recent years, hemostasis has been revised as a direct effector of 
immune innate response, and in 2013, Engelmann used the term "immunothrombosis" to define thrombosis as an uncontrolled, deranged immune response to tissue injury [124]. Moreover, several studies have demonstrated an association between NET production and thrombosis [125-128]. Recently, McDonald et al. demonstrated an in vivo intravascular coagulation into sinusoids in response to sepsis (LPS administration and S. aureus inoculation in mice), which colocalize with NETs formation and tissue injury [129]. Interestingly, in this experiment, NET inhibition reduced thrombin activation and organ damage, while anticoagulation with argatroban alone did not reveal any effect on tissue injury. Collectively, these results confirm that the interaction between immune responses, platelets and coagulation is crucial in organ homeostasis in response to exogenous damage stimuli [122]. Therefore, immunothrombosis may represent a global mechanism which mediates tissue injury in response to acute and chronic damage and precedes fibrosis. In hepatology, increasing evidence advocate a pathogenic role for bacterial translocation from gut to general circulation $[130,131]$. Bacterial translocation is due to the increase of portal hypertension alongside liver disease severity, thus increasing gut permeability and disrupting the intestinal barrier [132]. This chronic exposition of enteric pathogens is associated with a progressively worsening inflammatory state, which has been recently presumed to be one of the main pathophysiological events in the development of cirrhosis-related complications [132-134]. Bacterial translocation is also associated with VWF, FVIII increase and platelet hyperactivation, thus confirming a pro-hemostatic role [79,135-138]. As immunothrombosis may originate from excessive response to bacteria in the liver vasculature, the existence of a chronic pathogen exposition may be crucial in sustaining inflammation, micro-thrombosis and consequent parenchymal extinction. Studies on the potential link with immune response, hemostasis activation and consequent fibrosis and disease progression are intriguing and highly anticipated.

\section{Conclusions}

Hemostasis has a non-negligible impact on liver fibrosis, as it induces a pro-fibrotic, activated HSC phenotype through thrombin-PARs interaction. Moreover, the increasing comprehension of liver immunology elucidates the crucial role of hemostasis in tissue injury mechanisms and may offer new potential druggable pathways by further defining this complex interplay. A pro-hemostatic milieu in liver microcirculation due to repetitive harmful stimuli may drive sinusoidal microthrombosis, which leads to parenchymal extinction and disease progression (Figure 2). As a result, an inherited or acquired pro-hemostatic imbalance is associated with fibrosis progression in pre-clinical and clinical studies. Moreover, anticoagulant drugs reduce fibrosis development, and may impact the natural history of liver disease, even in late stages of cirrhosis, which display a complex hemostatic balance. Therefore, the ever more precise understanding of the mechanisms that regulate hemostasis and its interactions with the pathophysiology of tissue damage will make it possible to better define new therapeutic targets in the clinical challenge of dampening liver fibrosis. 


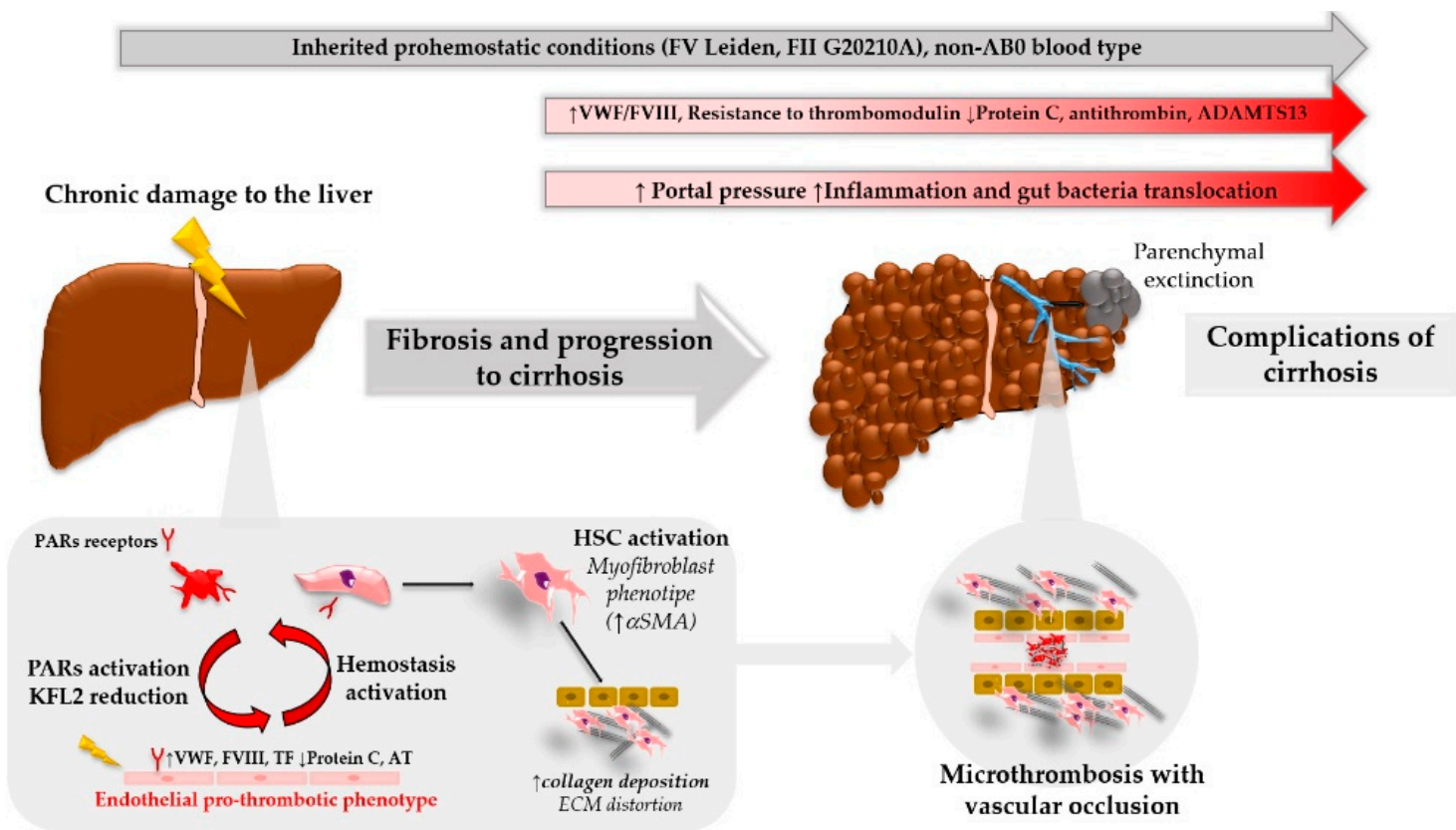

Figure 2. Hemostasis activation and liver disease progression.

Author Contributions: N.B. contributed to the systematic review of literature, and the design and writing of the manuscript; E.L. contributed to the systematic review of literature, and the writing of the manuscript; V.L.M. contributed to the supervision of the manuscript editing, and the revision of major intellectual content.

Funding: Authors received no external funding.

Conflicts of Interest: The authors declare no conflict of interest.

\section{References}

1. Hoffman, M.; Monroe, D.M. A cell-based model of hemostasis. Thromb. Haemost. 2001, 85, 958-965. [PubMed]

2. Weksler, B.B.; Ley, C.W.; Jaffe, E.A. Stimulation of Endothelial Cell Prostacyclin Production by Thrombin, Trypsin, and the Ionophore A 23187. J. Clin. Investig. 1978, 62, 923-930. [CrossRef] [PubMed]

3. Prescott, S.M.; Zimmerman, G.A.; McIntyre, T.M. Human endothelial cells in culture produce plateletactivating factor (1-alkyl-2-acetyl-sn-glycero-3-phosphocholine) when stimulated with thrombin. Proc. Natl. Acad. Sci. USA 1984, 81, 3534-3538. [CrossRef] [PubMed]

4. Sugama, Y.; Tiruppathi, C.; offakidevi, K.; Andersen, T.T.; Fenton, J.W.; Malik, A.B. Thrombin-induced expression of endothelial P-selectin and intercellular adhesion molecule-1: A mechanism for stabilizing neutrophil adhesion. J. Cell Biol. 1992, 119, 935-944. [CrossRef] [PubMed]

5. Laurens, N.; Koolwijk, P.; de Maat, M.P.M. Fibrin structure and wound healing. J. Thromb. Haemost. 2006, 4, 932-939. [CrossRef] [PubMed]

6. Vu, T.-K.H.; Hung, D.T.; Wheaton, V.I.; Coughlin, S.R. Molecular cloning of a functional thrombin receptor reveals a novel proteolytic mechanism of receptor activation. Cell 1991, 64, 1057-1068. [CrossRef]

7. Martorell, L.; Martínez-González, J.; Rodríguez, C.; Gentile, M.; Calvayrac, O.; Badimon, L. Thrombin and protease-activated receptors (PARs) in atherothrombosis. Thromb. Haemost. 2008, 99, 305-315. [CrossRef] [PubMed]

8. Kataoka, H.; Hamilton, J.R.; McKemy, D.D.; Camerer, E.; Zheng, Y.-W.; Cheng, A.; Griffin, C.; Coughlin, S.R. Protease-activated receptors 1 and 4 mediate thrombin signaling in endothelial cells. Blood 2003, 102, 3224-3231. [CrossRef] [PubMed]

9. Ramachandran, R.; Noorbakhsh, F.; Defea, K.; Hollenberg, M.D. Targeting proteinase-activated receptors: Therapeutic potential and challenges. Nat. Rev. Drug Discov. 2012, 11, 69-86. [CrossRef] [PubMed] 
10. Bae, J.-S.; Kim, Y.; Park, M.-K.; Rezaie, A.R. Concentration dependent dual effect of thrombin in endothelial cells via PAR-1 and PI3 kinase. J. Cell. Physiol. 2009, 219, 744-751. [CrossRef] [PubMed]

11. Wiisanen, M.E.; Moliterno, D.J. Platelet protease-activated receptor antagonism in cardiovascular medicine. Coron. Artery Dis. 2012, 23, 375-379. [CrossRef] [PubMed]

12. Isermann, B. Homeostatic effects of coagulation protease-dependent signaling and protease activated receptors. J. Thromb. Haemost. 2017, 15, 1273-1284. [CrossRef] [PubMed]

13. SenBanerjee, S.; Lin, Z.; Atkins, G.B.; Greif, D.M.; Rao, R.M.; Kumar, A.; Feinberg, M.W.; Chen, Z.; Simon, D.I.; Luscinskas, F.W.; et al. KLF2 Is a Novel Transcriptional Regulator of Endothelial Proinflammatory Activation. J. Exp. Med. 2004, 199, 1305-1315. [CrossRef] [PubMed]

14. Nayak, L.; Lin, Z.; Jain, M.K. "Go with the flow": How Krüppel-like factor 2 regulates the vasoprotective effects of shear stress. Antioxid. Redox Signal. 2011, 15, 1449-1461. [CrossRef] [PubMed]

15. Marrone, G.; Russo, L.; Rosado, E.; Hide, D.; García-Cardeña, G.; García-Pagán, J.C.; Bosch, J.; Gracia-Sancho, J. The transcription factor KLF2 mediates hepatic endothelial protection and paracrine endothelial-stellate cell deactivation induced by statins. J. Hepatol. 2013, 58, 98-103. [CrossRef] [PubMed]

16. Marrone, G.; Maeso-Díaz, R.; García-Cardena, G.; Abraldes, J.G.; García-Pagán, J.C.; Bosch, J.; Gracia-Sancho, J. KLF2 exerts antifibrotic and vasoprotective effects in cirrhotic rat livers: Behind the molecular mechanisms of statins. Gut 2014. [CrossRef] [PubMed]

17. Marrone, G.; Shah, V.H.; Gracia-Sancho, J. Sinusoidal communication in liver fibrosis and regeneration. J. Hepatol. 2016, 65, 608-617. [CrossRef] [PubMed]

18. Lin, Z.; Kumar, A.; SenBanerjee, S.; Staniszewski, K.; Parmar, K.; Vaughan, D.E.; Gimbrone, M.A.; Balasubramanian, V.; García-Cardeña, G.; Jain, M.K. Kruppel-like factor 2 (KLF2) regulates endothelial thrombotic function. Circ. Res. 2005, 96, e48-e57. [CrossRef] [PubMed]

19. Uemura, M.; Tatsumi, K.; Matsumoto, M.; Fujimoto, M.; Matsuyama, T.; Ishikawa, M.; Iwamoto, T.-A.; Mori, T.; Wanaka, A.; Fukui, H.; et al. Localization of ADAMTS13 to the stellate cells of human liver. Blood 2005, 106, 922-924. [CrossRef] [PubMed]

20. Uemura, M.; Fujimura, Y.; Matsumoto, M.; Ishizashi, H.; Kato, S.; Matsuyama, T.; Isonishi, A.; Ishikawa, M.; Yagita, M.; Morioka, C.; et al. Comprehensive analysis of ADAMTS13 in patients with liver cirrhosis. Thromb. Haemost. 2008, 99, 1019-1029. [CrossRef] [PubMed]

21. Levy, G.G.; Nichols, W.C.; Lian, E.C.; Foroud, T.; McClintick, J.N.; McGee, B.M.; Yang, A.Y.; Siemieniak, D.R.; Stark, K.R.; Gruppo, R.; et al. Mutations in a member of the ADAMTS gene family cause thrombotic thrombocytopenic purpura. Nature 2001, 413, 488-494. [CrossRef] [PubMed]

22. Levi, M.; Scully, M.; Singer, M. The role of ADAMTS-13 in the coagulopathy of sepsis. J. Thromb. Haemost. 2018. [CrossRef] [PubMed]

23. García-Pagán, J.-C.; Gracia-Sancho, J.; Bosch, J. Functional aspects on the pathophysiology of portal hypertension in cirrhosis. J. Hepatol. 2012, 57, 458-461. [CrossRef] [PubMed]

24. Chambers, R.C.; Dabbagh, K.; McAnulty, R.J.; Gray, A.J.; Blanc-Brude, O.P.; Laurent, G.J. Thrombin stimulates fibroblast procollagen production via proteolytic activation of protease-activated receptor 1. Biochem. J. 1998, 333, 121-127. [CrossRef] [PubMed]

25. Gaça, M.D.A.; Zhou, X.; Benyon, R.C. Regulation of hepatic stellate cell proliferation and collagen synthesis by proteinase-activated receptors. J. Hepatol. 2002, 36, 362-369. [CrossRef]

26. Fiorucci, S.; Antonelli, E.; Distrutti, E.; Severino, B.; Fiorentina, R.; Baldoni, M.; Caliendo, G.; Santagada, V.; Morelli, A.; Cirino, G. PAR1 antagonism protects against experimental liver fibrosis. Role of proteinase receptors in stellate cell activation. Hepatology 2004, 39, 365-375. [CrossRef] [PubMed]

27. Anstee, Q.M.; Dhar, A.; Thursz, M.R. The role of hypercoagulability in liver fibrogenesis. Clin. Res. Hepatol. Gastroenterol. 2011, 35, 526-533. [CrossRef] [PubMed]

28. Duplantier, J.G.; Dubuisson, L.; Senant, N.; Freyburger, G.; Laurendeau, I.; Herbert, J.-M.; Desmoulière, A.; Rosenbaum, J. A role for thrombin in liver fibrosis. Gut 2004, 53, 1682-1687. [CrossRef] [PubMed]

29. Takahara, T.; Furui, K.; Funaki, J.; Nakayama, Y.; Itoh, H.; Miyabayashi, C.; Sato, H.; Seiki, M.; Ooshima, A.; Watanabe, A. Increased expression of matrix metalloproteinase-II in experimental liver fibrosis in rats. Hepatology 1995, 21, 787-795. [PubMed]

30. Knight, V.; Lourensz, D.; Tchongue, J.; Correia, J.; Tipping, P.; Sievert, W. Cytoplasmic domain of tissue factor promotes liver fibrosis in mice. World J. Gastroenterol. 2017, 23, 5692-5699. [CrossRef] [PubMed] 
31. Knight, V.; Tchongue, J.; Lourensz, D.; Tipping, P.; Sievert, W. Protease-activated receptor 2 promotes experimental liver fibrosis in mice and activates human hepatic stellate cells. Hepatology 2012, 55, 879-887. [CrossRef] [PubMed]

32. Rullier, A.; Gillibert-Duplantier, J.; Costet, P.; Cubel, G.; Haurie, V.; Petibois, C.; Taras, D.; Dugot-Senant, N.; Deleris, G.; Bioulac-Sage, P.; et al. Protease-activated receptor 1 knockout reduces experimentally induced liver fibrosis. Am. J. Physiol. Gastrointest. Liver Physiol. 2008, 294, G226-G235. [CrossRef] [PubMed]

33. Sullivan, B.P.; Weinreb, P.H.; Violette, S.M.; Luyendyk, J.P. The Coagulation System Contributes to $\alpha$ V $\beta 6$ Integrin Expression and Liver Fibrosis Induced by Cholestasis. Am. J. Pathol. 2010, 177, 2837-2849. [CrossRef] [PubMed]

34. Nault, R.; Fader, K.A.; Kopec, A.K.; Harkema, J.R.; Zacharewski, T.R.; Luyendyk, J.P. From the Cover: Coagulation-Driven Hepatic Fibrosis Requires Protease Activated Receptor-1 (PAR-1) in a Mouse Model of TCDD-Elicited Steatohepatitis. Toxicol. Sci. 2016, 154, 381-391. [CrossRef] [PubMed]

35. Martinelli, A.; Knapp, S.; Anstee, Q.; Worku, M.; Tommasi, A.; Zucoloto, S.; Goldin, R.; Thursz, M. Effect of a thrombin receptor (protease-activated receptor 1, PAR-1) gene polymorphism in chronic hepatitis C liver fibrosis. J. Gastroenterol. Hepatol. 2008, 23, 1403-1409. [CrossRef] [PubMed]

36. Mackman, N. Role of Tissue Factor in Hemostasis, Thrombosis, and Vascular Development. Arterioscler. Thromb. Vasc. Biol. 2004, 24, 1015-1022. [CrossRef] [PubMed]

37. Rautou, P.-E.; Tatsumi, K.; Antoniak, S.; Owens, A.P.; Sparkenbaugh, E.; Holle, L.A.; Wolberg, A.S.; Kopec, A.K.; Pawlinski, R.; Luyendyk, J.P.; et al. Hepatocyte Tissue Factor Contributes to the Hypercoagulable State in a Mouse Model of Chronic Liver Injury. J. Hepatol. 2015. [CrossRef] [PubMed]

38. Gillibert-Duplantier, J.; Neaud, V.; Blanc, J.-F.; Bioulac-Sage, P.; Rosenbaum, J. Thrombin inhibits migration of human hepatic myofibroblasts. Am. J. Physiol. Gastrointest. Liver Physiol. 2007, 293, G128-G136. [CrossRef] [PubMed]

39. Wanless, I.R.; Wong, F.; Blendis, L.M.; Greig, P.; Heathcote, E.J.; Levy, G. Hepatic and portal vein thrombosis in cirrhosis: Possible role in development of parenchymal extinction and portal hypertension. Hepatology 1995, 21, 1238-1247. [PubMed]

40. Hou, P.C.; Mcfadzean, A.J. Thrombosis and Intimal Thickening in the Portal System in Cirrhosis of the Liver. J. Pathol. Bacteriol. 1965, 89, 473-480. [PubMed]

41. Wanless, I.R.; Liu, J.J.; Butany, J. Role of thrombosis in the pathogenesis of congestive hepatic fibrosis (cardiac cirrhosis). Hepatology 1995, 21, 1232-1237. [CrossRef] [PubMed]

42. Simonetto, D.A.; Yang, H.; Yin, M.; de Assuncao, T.M.; Kwon, J.H.; Hilscher, M.; Pan, S.; Yang, L.; Bi, Y.; Beyder, A.; et al. Chronic passive venous congestion drives hepatic fibrogenesis via sinusoidal thrombosis and mechanical forces. Hepatology 2015, 61, 648-659. [CrossRef] [PubMed]

43. Miyao, M.; Kotani, H.; Ishida, T.; Kawai, C.; Manabe, S.; Abiru, H.; Tamaki, K. Pivotal role of liver sinusoidal endothelial cells in NAFLD/NASH progression. Lab. Investig. 2015, 95, 1130-1144. [CrossRef] [PubMed]

44. de Ridder, G.G.; Lundblad, R.L.; Pizzo, S.V. Actions of thrombin in the interstitium. J. Thromb. Haemost. 2016, 14, 40-47. [CrossRef] [PubMed]

45. Koo, B.-H.; Han, J.H.; Yeom, Y.I.; Kim, D.-S. Thrombin-dependent MMP-2 activity is regulated by heparan sulfate. J. Biol. Chem. 2010, 285, 41270-41279. [CrossRef] [PubMed]

46. Cabrera, S.; Gaxiola, M.; Arreola, J.L.; Ramírez, R.; Jara, P.; D’Armiento, J.; Richards, T.; Selman, M.; Pardo, A. Overexpression of MMP9 in macrophages attenuates pulmonary fibrosis induced by bleomycin. Int. J. Biochem. Cell Biol. 2007, 39, 2324-2338. [CrossRef] [PubMed]

47. Villa, E.; Cammà, C.; Marietta, M.; Luongo, M.; Critelli, R.; Colopi, S.; Tata, C.; Zecchini, R.; Gitto, S.; Petta, S.; et al. Enoxaparin prevents portal vein thrombosis and liver decompensation in patients with advanced cirrhosis. Gastroenterology 2012, 143, 1253-1260.e4. [CrossRef] [PubMed]

48. La Mura, V.; Braham, S.; Tosetti, G.; Branchi, F.; Bitto, N.; Moia, M.; Fracanzani, A.L.; Colombo, M.; Tripodi, A.; Primignani, M. Harmful and Beneficial Effects of Anticoagulants in Patients With Cirrhosis and Portal Vein Thrombosis. Clin. Gastroenterol. Hepatol. 2018, 16, 1146-1152. [CrossRef] [PubMed]

49. Ho, W.K.; Hankey, G.J.; Quinlan, D.J.; Eikelboom, J.W. Risk of recurrent venous thromboembolism in patients with common thrombophilia: A systematic review. Arch. Intern. Med. 2006, 166, 729-736. [CrossRef] [PubMed] 
50. Marchiori, A.; Mosena, L.; Prins, M.H.; Prandoni, P. The risk of recurrent venous thromboembolism among heterozygous carriers of factor V Leiden or prothrombin G20210A mutation. A systematic review of prospective studies. Haematologica 2007, 92, 1107-1114. [CrossRef] [PubMed]

51. Connors, J.M. Thrombophilia Testing and Venous Thrombosis. N. Engl. J. Med. 2017, 377, 1177-1187. [CrossRef] [PubMed]

52. Colucci, M.; Binetti, B.M.; Tripodi, A.; Chantarangkul, V.; Semeraro, N. Hyperprothrombinemia associated with prothrombin G20210A mutation inhibits plasma fibrinolysis through a TAFI-mediated mechanism. Blood 2004, 103, 2157-2161. [CrossRef] [PubMed]

53. Van Cott, E.M.; Khor, B.; Zehnder, J.L. Factor V Leiden. Am. J. Hematol. 2016, 91, 46-49. [CrossRef] [PubMed]

54. Wright, M.; Goldin, R.; Hellier, S.; Knapp, S.; Frodsham, A.; Hennig, B.; Hill, A.; Apple, R.; Cheng, S.; Thomas, H.; et al. Factor V Leiden polymorphism and the rate of fibrosis development in chronic hepatitis $\mathrm{C}$ virus infection. Gut 2003, 52, 1206-1210. [CrossRef] [PubMed]

55. Maharshak, N.; Halfon, P.; Deutsch, V.; Peretz, H.; Berliner, S.; Fishman, S.; Zelber-Sagi, S.; Rozovski, U.; Leshno, M.; Oren, R. Increased fibrosis progression rates in hepatitis $C$ patients carrying the prothrombin G20210A mutation. World J. Gastroenterol. 2011, 17, 5007-5013. [CrossRef] [PubMed]

56. Plompen, E.P.C.; Murad, S.D.; Hansen, B.E.; Loth, D.W.; Schouten, J.N.L.; Taimr, P.; Hofman, A.; Uitterlinden, A.G.; Stricker, B.H.; Janssen, H.L.A.; et al. Prothrombotic genetic risk factors are associated with an increased risk of liver fibrosis in the general population: The Rotterdam Study. J. Hepatol. 2015, 63, 1459-1465. [CrossRef] [PubMed]

57. Assy, N.; Bekirov, I.; Mejritsky, Y.; Solomon, L.; Szvalb, S.; Hussein, O. Association between thrombotic risk factors and extent of fibrosis in patients with non-alcoholic fatty liver diseases. World J. Gastroenterol. 2005, 11, 5834-5839. [CrossRef] [PubMed]

58. D'Amico, M.; Pasta, F.; Pasta, L. Thrombophilic genetic factors PAI-1 4G-4G and MTHFR 677TT as risk factors of alcohol, cryptogenic liver cirrhosis and portal vein thrombosis, in a Caucasian population. Gene 2015, 568, 85-88. [CrossRef] [PubMed]

59. Poujol-Robert, A.; Rosmorduc, O.; Serfaty, L.; Coulet, F.; Poupon, R.; Robert, A. Genetic and acquired thrombotic factors in chronic hepatitis C. Am. J. Gastroenterol. 2004, 99, 527-531. [CrossRef] [PubMed]

60. Goulding, C.; O’Brien, C.; Egan, H.; Hegarty, J.E.; McDonald, G.; O'Farrelly, C.; White, B.; Kelleher, D.; Norris, S. The impact of inherited prothrombotic risk factors on individuals chronically infected with hepatitis C virus from a single source. J. Viral Hepat. 2007, 14, 255-259. [CrossRef] [PubMed]

61. Poujol-Robert, A.; Boëlle, P.-Y.; Wendum, D.; Poupon, R.; Robert, A. Association between ABO blood group and fibrosis severity in chronic hepatitis C infection. Dig. Dis. Sci. 2006, 51, 1633-1636. [CrossRef] [PubMed]

62. Shavakhi, A.; Hajalikhani, M.; Minakari, M.; Norian, A.; Riahi, R.; Azarnia, M.; Liaghat, L. The association of non-O blood group and severity of liver fibrosis in patients with chronic hepatitis C infection. J. Res. Med. Sci. 2012, 17, 466-469. [PubMed]

63. Koster, T.; Vandenbroucke, J.P.; Rosendaal, F.R.; Briët, E.; Rosendaal, F.R.; Blann, A.D. Role of clotting factor VIII in effect of von Willebrand factor on occurrence of deep-vein thrombosis. Lancet 1995, 345, 152-155. [CrossRef]

64. O'Donnell, J.; Laffan, M.A. The relationship between ABO histo-blood group, factor VIII and von Willebrand factor. Transfus. Med. 2001, 11, 343-351. [CrossRef] [PubMed]

65. Tripodi, A.; Mannucci, P.M. The coagulopathy of chronic liver disease. N. Engl. J. Med. 2011, 365, 147-156. [CrossRef] [PubMed]

66. Ratnoff, O.D.; Patek, A.J. The Natural History of Laennec's Cirrhosis of the Liver an Analysis of 386 Cases. Medicine 1942, 21, 207-268. [CrossRef]

67. La Mura, V.; Nicolini, A.; Tosetti, G.; Primignani, M. Cirrhosis and portal hypertension: The importance of risk stratification, the role of hepatic venous pressure gradient measurement. World J. Hepatol. 2015, 7 , 688-695. [CrossRef] [PubMed]

68. Tripodi, A.; Salerno, F.; Chantarangkul, V.; Clerici, M.; Cazzaniga, M.; Primignani, M.; Mannuccio Mannucci, P. Evidence of normal thrombin generation in cirrhosis despite abnormal conventional coagulation tests. Hepatology 2005, 41, 553-558. [CrossRef] [PubMed]

69. Lisman, T.; Porte, R.J. Rebalanced hemostasis in patients with liver disease: Evidence and clinical consequences. Blood 2010, 116, 878-885. [CrossRef] [PubMed] 
70. Tripodi, A.; Primignani, M.; Mannucci, P.M.; Caldwell, S.H. Changing Concepts of Cirrhotic Coagulopathy. Am. J. Gastroenterol. 2017, 112, 274-281. [CrossRef] [PubMed]

71. Tripodi, A.; Primignani, M.; Chantarangkul, V.; Dell’Era, A.; Clerici, M.; de Franchis, R.; Colombo, M.; Mannucci, P.M. An imbalance of pro- vs. anti-coagulation factors in plasma from patients with cirrhosis. Gastroenterology 2009, 137, 2105-2111. [CrossRef] [PubMed]

72. Tripodi, A.; Primignani, M.; Lemma, L.; Chantarangkul, V.; Mannucci, P.M. Evidence that low protein C contributes to the procoagulant imbalance in cirrhosis. J. Hepatol. 2013, 59, 265-270. [CrossRef] [PubMed]

73. Ambrosino, P.; Tarantino, L.; Minno, G.D.; Paternoster, M.; Graziano, V.; Petitto, M.; Nasto, A.; Minno, M.N.D.D. The risk of venous thromboembolism in patients with cirrhosis. Thromb. Haemost. 2017, 117, 139-148. [CrossRef] [PubMed]

74. Nonami, T.; Yokoyama, I.; Iwatsuki, S.; Starzl, T.E. The Incidence of Portal Vein Thrombosis at Liver Transplantation. Hepatology 1992, 16, 1195-1198. [CrossRef] [PubMed]

75. Tsochatzis, E.A.; Senzolo, M.; Germani, G.; Gatt, A.; Burroughs, A.K. Systematic review: Portal vein thrombosis in cirrhosis. Aliment. Pharmacol. Ther. 2010, 31, 366-374. [CrossRef] [PubMed]

76. Northup, P.G.; McMahon, M.M.; Ruhl, A.P.; Altschuler, S.E.; Volk-Bednarz, A.; Caldwell, S.H.; Berg, C.L. Coagulopathy does not fully protect hospitalized cirrhosis patients from peripheral venous thromboembolism. Am. J. Gastroenterol. 2006, 101, 1524-1528. [CrossRef] [PubMed]

77. Søgaard, K.K.; Horváth-Puhó, E.; Grønbaek, H.; Jepsen, P.; Vilstrup, H.; Sørensen, H.T. Risk of venous thromboembolism in patients with liver disease: A nationwide population-based case-control study. Am. J. Gastroenterol. 2009, 104, 96-101. [CrossRef] [PubMed]

78. Wu, H.; Nguyen, G.C. Liver cirrhosis is associated with venous thromboembolism among hospitalized patients in a nationwide US study. Clin. Gastroenterol. Hepatol. 2010, 8, 800-805. [CrossRef] [PubMed]

79. Ferro, D.; Quintarelli, C.; Lattuada, A.; Leo, R.; Alessandroni, M.; Mannucci, P.M.; Violi, F. High plasma levels of von Willebrand factor as a marker of endothelial perturbation in cirrhosis: Relationship to endotoxemia. Hepatology 1996, 23, 1377-1383. [CrossRef] [PubMed]

80. Albornoz, L.; Alvarez, D.; Otaso, J.C.; Gadano, A.; Salviú, J.; Gerona, S.; Sorroche, P.; Villamil, A.; Mastai, R. Von Willebrand factor could be an index of endothelial dysfunction in patients with cirrhosis: Relationship to degree of liver failure and nitric oxide levels. J. Hepatol. 1999, 30, 451-455. [CrossRef]

81. La Mura, V.; Reverter, J.C.; Flores-Arroyo, A.; Raffa, S.; Reverter, E.; Seijo, S.; Abraldes, J.G.; Bosch, J.; García-Pagán, J.C. Von Willebrand factor levels predict clinical outcome in patients with cirrhosis and portal hypertension. Gut 2011, 60, 1133-1138. [CrossRef] [PubMed]

82. Ferlitsch, M.; Reiberger, T.; Hoke, M.; Salzl, P.; Schwengerer, B.; Ulbrich, G.; Payer, B.A.; Trauner, M.; Peck-Radosavljevic, M.; Ferlitsch, A. von Willebrand factor as new noninvasive predictor of portal hypertension, decompensation and mortality in patients with liver cirrhosis. Hepatology 2012, 56, 1439-1447. [CrossRef] [PubMed]

83. La Mura, V.; Tripodi, A.; Tosetti, G.; Cavallaro, F.; Chantarangkul, V.; Colombo, M.; Primignani, M. Resistance to thrombomodulin is associated with de novo portal vein thrombosis and low survival in patients with cirrhosis. Liver Int. 2016, 36, 1322-1330. [CrossRef] [PubMed]

84. Kalambokis, G.N.; Oikonomou, A.; Baltayiannis, G.; Christou, L.; Kolaitis, N.I.; Tsianos, E.V. Thrombin generation measured as thrombin-antithrombin complexes predicts clinical outcomes in patients with cirrhosis. Hepatol. Res. 2015. [CrossRef] [PubMed]

85. Kalambokis, G.N.; Oikonomou, A.; Christou, L.; Kolaitis, N.I.; Tsianos, E.V.; Christodoulou, D.; Baltayiannis, G. von Willebrand factor and procoagulant imbalance predict outcome in patients with cirrhosis and thrombocytopenia. J. Hepatol. 2016, 65, 921-928. [CrossRef] [PubMed]

86. Maieron, A.; Salzl, P.; Peck-Radosavljevic, M.; Trauner, M.; Hametner, S.; Schöfl, R.; Ferenci, P.; Ferlitsch, M. Von Willebrand Factor as a new marker for non-invasive assessment of liver fibrosis and cirrhosis in patients with chronic hepatitis C. Aliment. Pharmacol. Ther. 2014, 39, 331-338. [CrossRef] [PubMed]

87. Hametner, S.; Ferlitsch, A.; Ferlitsch, M.; Etschmaier, A.; Schöfl, R.; Ziachehabi, A.; Maieron, A. The VITRO Score (Von Willebrand Factor Antigen/Thrombocyte Ratio) as a New Marker for Clinically Significant Portal Hypertension in Comparison to Other Non-Invasive Parameters of Fibrosis Including ELF Test. PLoS ONE 2016, 11, e0149230. [CrossRef] [PubMed] 
88. Tripodi, A.; Fracanzani, A.L.; Primignani, M.; Chantarangkul, V.; Clerici, M.; Mannucci, P.M.; Peyvandi, F.; Bertelli, C.; Valenti, L.; Fargion, S. Procoagulant imbalance in patients with non-alcoholic fatty liver disease. J. Hepatol. 2014, 61, 148-154. [CrossRef] [PubMed]

89. Wong, R.J.; Aguilar, M.; Cheung, R.; Perumpail, R.B.; Harrison, S.A.; Younossi, Z.M.; Ahmed, A. Nonalcoholic steatohepatitis is the second leading etiology of liver disease among adults awaiting liver transplantation in the United States. Gastroenterology 2015, 148, 547-555. [CrossRef] [PubMed]

90. Younossi, Z.M.; Koenig, A.B.; Abdelatif, D.; Fazel, Y.; Henry, L.; Wymer, M. Global Epidemiology of Non-Alcoholic Fatty Liver Disease-Meta-Analytic Assessment of Prevalence, Incidence and Outcomes. Hepatology 2015. [CrossRef]

91. Potze, W.; Siddiqui, M.S.; Boyett, S.L.; Adelmeijer, J.; Daita, K.; Sanyal, A.J.; Lisman, T. Preserved hemostatic status in patients with non-alcoholic fatty liver disease. J. Hepatol. 2016, 65, 980-987. [CrossRef] [PubMed]

92. Tripodi, A.; Fracanzani, A.L.; Chantarangkul, V.; Primignani, M.; Fargion, S. Procoagulant imbalance in patients with non-alcoholic fatty liver disease. J. Hepatol. 2017, 66, 248-250. [CrossRef] [PubMed]

93. Potze, W.; Sanyal, A.J.; Lisman, T. Reply to: "Procoagulant imbalance in patients with non-alcoholic fatty liver disease.". J. Hepatol. 2017, 66, 250-251. [CrossRef] [PubMed]

94. Bruno, S.; Di Marco, V.; Iavarone, M.; Roffi, L.; Crosignani, A.; Calvaruso, V.; Aghemo, A.; Cabibbo, G.; Viganò, M.; Boccaccio, V.; et al. Survival of patients with HCV cirrhosis and sustained virologic response is similar to the general population. J. Hepatol. 2016, 64, 1217-1223. [CrossRef] [PubMed]

95. Schuppan, D.; Pinzani, M. Anti-fibrotic therapy: Lost in translation? J. Hepatol. 2012, 56 (Suppl. 1), S66-S74. [CrossRef]

96. Schuppan, D.; Ashfaq-Khan, M.; Yang, A.T.; Kim, Y.O. Liver fibrosis: Direct antifibrotic agents and targeted therapies. Matrix Biol. 2018. [CrossRef] [PubMed]

97. Hirsh, J.; Levine, M.N. Low molecular weight heparin. Blood 1992, 79, 1-17. [CrossRef] [PubMed]

98. Li, C.-J.; Yang, Z.-H.; Shi, X.-L.; Liu, D.-L. Effects of aspirin and enoxaparin in a rat model of liver fibrosis. World J. Gastroenterol. 2017, 23, 6412-6419. [CrossRef] [PubMed]

99. Abe, W.; Ikejima, K.; Lang, T.; Okumura, K.; Enomoto, N.; Kitamura, T.; Takei, Y.; Sato, N. Low molecular weight heparin prevents hepatic fibrogenesis caused by carbon tetrachloride in the rat. J. Hepatol. 2007, 46, 286-294. [CrossRef] [PubMed]

100. Cerini, F.; Vilaseca, M.; Lafoz, E.; García-Irigoyen, O.; García-Calderó, H.; Tripathi, D.M.; Avila, M.; Reverter, J.C.; Bosch, J.; Gracia-Sancho, J.; et al. Enoxaparin reduces hepatic vascular resistance and portal pressure in cirrhotic rats. J. Hepatol. 2016, 64, 834-842. [CrossRef] [PubMed]

101. Anstee, Q.M.; Goldin, R.D.; Wright, M.; Martinelli, A.; Cox, R.; Thursz, M.R. Coagulation status modulates murine hepatic fibrogenesis: Implications for the development of novel therapies. J. Thromb. Haemost. 2008, 6, 1336-1343. [CrossRef] [PubMed]

102. Kassel, K.M.; Sullivan, B.P.; Cui, W.; Copple, B.L.; Luyendyk, J.P. Therapeutic administration of the direct thrombin inhibitor argatroban reduces hepatic inflammation in mice with established fatty liver disease. Am. J. Pathol. 2012, 181, 1287-1295. [CrossRef] [PubMed]

103. Vilaseca, M.; García-Calderó, H.; Lafoz, E.; García-Irigoyen, O.; Avila, M.A.; Reverter, J.C.; Bosch, J.; Hernández-Gea, V.; Gracia-Sancho, J.; García-Pagán, J.C. The anticoagulant rivaroxaban lowers portal hypertension in cirrhotic rats mainly by deactivating hepatic stellate cells. Hepatology 2017, 65, 2031-2044. [CrossRef] [PubMed]

104. Bell, R.G.; Sadowski, J.A.; Matschiner, J.T. Mechanism of action of warfarin. Warfarin and metabolism of vitamin K1. Biochemistry 1972, 11, 1959-1961. [CrossRef] [PubMed]

105. Kirkwood, T.B. Calibration of reference thromboplastins and standardisation of the prothrombin time ratio. Thromb. Haemost. 1983, 49, 238-244. [CrossRef] [PubMed]

106. Ansell, J.; Hirsh, J.; Hylek, E.; Jacobson, A.; Crowther, M.; Palareti, G. Pharmacology and management of the vitamin K antagonists: American College of Chest Physicians Evidence-Based Clinical Practice Guidelines (8th Edition). Chest 2008, 133, 160S-198S. [CrossRef] [PubMed]

107. Barnes, G.D.; Kurtz, B. Direct oral anticoagulants: Unique properties and practical approaches to management. Heart 2016, 102, 1620-1626. [CrossRef] [PubMed]

108. Barnes, G.D.; Lucas, E.; Alexander, G.C.; Goldberger, Z.D. National Trends in Ambulatory Oral Anticoagulant Use. Am. J. Med. 2015, 128, 1300-1305.e2. [CrossRef] [PubMed] 
109. Intagliata, N.M.; Maitland, H.; Caldwell, S.H. Direct Oral Anticoagulants in Cirrhosis. Curr. Treat. Opt. Gastroenterol. 2016, 14, 247-256. [CrossRef] [PubMed]

110. Intagliata, N.M.; Henry, Z.H.; Maitland, H.; Shah, N.L.; Argo, C.K.; Northup, P.G.; Caldwell, S.H. Direct Oral Anticoagulants in Cirrhosis Patients Pose Similar Risks of Bleeding When Compared to Traditional Anticoagulation. Dig. Dis. Sci. 2016. [CrossRef] [PubMed]

111. Hum, J.; Shatzel, J.J.; Jou, J.H.; Deloughery, T.G. The efficacy and safety of direct oral anticoagulants vs. traditional anticoagulants in cirrhosis. Eur. J. Haematol. 2017, 98, 393-397. [CrossRef] [PubMed]

112. De Gottardi, A.; Trebicka, J.; Klinger, C.; Plessier, A.; Seijo, S.; Terziroli, B.; Magenta, L.; Semela, D.; Buscarini, E.; Langlet, P.; et al. Antithrombotic treatment with direct-acting oral anticoagulants in patients with splanchnic vein thrombosis and cirrhosis. Liver Int. 2017, 37, 694-699. [CrossRef] [PubMed]

113. Marques, P.E.; Antunes, M.M.; David, B.A.; Pereira, R.V.; Teixeira, M.M.; Menezes, G.B. Imaging liver biology in vivo using conventional confocal microscopy. Nat. Protoc. 2015, 10, 258-268. [CrossRef] [PubMed]

114. Wang, J.; Hossain, M.; Thanabalasuriar, A.; Gunzer, M.; Meininger, C.; Kubes, P. Visualizing the function and fate of neutrophils in sterile injury and repair. Science 2017, 358, 111-116. [CrossRef] [PubMed]

115. McDonald, B.; Jenne, C.N.; Zhuo, L.; Kimata, K.; Kubes, P. Kupffer cells and activation of endothelial TLR4 coordinate neutrophil adhesion within liver sinusoids during endotoxemia. Am. J. Physiol. Gastrointest. Liver Physiol. 2013, 305, G797-G806. [CrossRef] [PubMed]

116. Kolaczkowska, E.; Jenne, C.N.; Surewaard, B.G.J.; Thanabalasuriar, A.; Lee, W.-Y.; Sanz, M.-J.; Mowen, K.; Opdenakker, G.; Kubes, P. Molecular mechanisms of NET formation and degradation revealed by intravital imaging in the liver vasculature. Nat. Commun. 2015, 6, 6673. [CrossRef] [PubMed]

117. Weber, C. Liver: Neutrophil extracellular traps mediate bacterial liver damage. Nat. Rev. Gastroenterol. Hepatol. 2015, 12, 251. [CrossRef] [PubMed]

118. Andrews, R.K.; Arthur, J.F.; Gardiner, E.E. Neutrophil extracellular traps (NETs) and the role of platelets in infection. Thromb. Haemost. 2014, 112, 659-665. [CrossRef] [PubMed]

119. Brinkmann, V.; Reichard, U.; Goosmann, C.; Fauler, B.; Uhlemann, Y.; Weiss, D.S.; Weinrauch, Y.; Zychlinsky, A. Neutrophil extracellular traps kill bacteria. Science 2004, 303, 1532-1535. [CrossRef] [PubMed]

120. Yipp, B.G.; Kubes, P. NETosis: How vital is it? Blood 2013, 122, 2784-2794. [CrossRef] [PubMed]

121. Healy, L.D.; Puy, C.; Itakura, A.; Chu, T.; Robinson, D.K.; Bylund, A.; Phillips, K.G.; Gardiner, E.E.; McCarty, O.J.T. Colocalization of neutrophils, extracellular DNA and coagulation factors during NETosis: Development and utility of an immunofluorescence-based microscopy platform. J. Immunol. Methods 2016. [CrossRef] [PubMed]

122. Deppermann, C.; Kubes, P. Platelets and infection. Semin. Immunol. 2016. [CrossRef] [PubMed]

123. Ward, C.M.; Tetaz, T.J.; Andrews, R.K.; Berndt, M.C. Binding of the von Willebrand factor A1 domain to histone. Thromb. Res. 1997, 86, 469-477. [CrossRef]

124. Engelmann, B.; Massberg, S. Thrombosis as an intravascular effector of innate immunity. Nat. Rev. Immunol. 2013, 13, 34-45. [CrossRef] [PubMed]

125. Diaz, J.A.; Fuchs, T.A.; Jackson, T.O.; Kremer Hovinga, J.A.; Lämmle, B.; Henke, P.K.; Myers, D.D.; Wagner, D.D.; Wakefield, T.W.; Michigan Research Venous Group. Plasma DNA is Elevated in Patients with Deep Vein Thrombosis. J. Vasc. Surg. Venous Lymphat Disord. 2013, 1. [CrossRef]

126. Liaw, P.C.; Ito, T.; Iba, T.; Thachil, J.; Zeerleder, S. DAMP and DIC: The role of extracellular DNA and DNA-binding proteins in the pathogenesis of DIC. Blood Rev. 2015. [CrossRef] [PubMed]

127. Yang, C.; Sun, W.; Cui, W.; Li, X.; Yao, J.; Jia, X.; Li, C.; Wu, H.; Hu, Z.; Zou, X. Procoagulant role of neutrophil extracellular traps in patients with gastric cancer. Int. J. Clin. Exp. Pathol. 2015, 8, 14075-14086. [PubMed]

128. Michels, A.; Albánez, S.; Mewburn, J.; Nesbitt, K.; Gould, T.J.; Liaw, P.C.; James, P.D.; Swystun, L.L.; Lillicrap, D. Histones link inflammation and thrombosis through the induction of Weibel-Palade Body exocytosis. J. Thromb. Haemost. 2016. [CrossRef] [PubMed]

129. McDonald, B.; Davis, R.P.; Kim, S.-J.; Tse, M.; Esmon, C.T.; Kolaczkowska, E.; Jenne, C.N. Platelets and neutrophil extracellular traps collaborate to promote intravascular coagulation during sepsis in mice. Blood 2017. [CrossRef] [PubMed]

130. Cirera, I.; Bauer, T.M.; Navasa, M.; Vila, J.; Grande, L.; Taurá, P.; Fuster, J.; García-Valdecasas, J.C.; Lacy, A.; Suárez, M.J.; et al. Bacterial translocation of enteric organisms in patients with cirrhosis. J. Hepatol. 2001, 34, 32-37. [CrossRef] 
131. Wiest, R.; Lawson, M.; Geuking, M. Pathological bacterial translocation in liver cirrhosis. J. Hepatol. 2014, 60, 197-209. [CrossRef] [PubMed]

132. Bellot, P.; Francés, R.; Such, J. Pathological bacterial translocation in cirrhosis: Pathophysiology, diagnosis and clinical implications. Liver Int. 2013, 33, 31-39. [CrossRef] [PubMed]

133. Bellot, P.; García-Pagán, J.C.; Francés, R.; Abraldes, J.G.; Navasa, M.; Pérez-Mateo, M.; Such, J.; Bosch, J. Bacterial DNA translocation is associated with systemic circulatory abnormalities and intrahepatic endothelial dysfunction in patients with cirrhosis. Hepatology 2010, 52, 2044-2052. [CrossRef] [PubMed]

134. Bernardi, M.; Moreau, R.; Angeli, P.; Schnabl, B.; Arroyo, V. Mechanisms of decompensation and organ failure in cirrhosis: From peripheral arterial vasodilation to systemic inflammation hypothesis. J. Hepatol. 2015, 63, 1272-1284. [CrossRef] [PubMed]

135. Violi, F.; Ferro, D.; Basili, S.; Saliola, M.; Quintarelli, C.; Alessandri, C.; Cordova, C. Association between low-grade disseminated intravascular coagulation and endotoxemia in patients with liver cirrhosis. Gastroenterology 1995, 109, 531-539. [CrossRef]

136. Ferro, D.; Basili, S.; Lattuada, A.; Mantovani, B.; Bellomo, A.; Mannucci, P.M.; Violi, F. Systemic clotting activation by low-grade endotoxaemia in liver cirrhosis: A potential role for endothelial procoagulant activation. Ital. J. Gastroenterol. Hepatol. 1997, 29, 434-440. [PubMed]

137. Raparelli, V.; Basili, S.; Carnevale, R.; Napoleone, L.; Del Ben, M.; Nocella, C.; Bartimoccia, S.; Lucidi, C.; Talerico, G.; Riggio, O.; et al. Low-grade endotoxemia and platelet activation in cirrhosis. Hepatology 2016. [CrossRef] [PubMed]

138. Carnevale, R.; Raparelli, V.; Nocella, C.; Bartimoccia, S.; Novo, M.; Severino, A.; De Falco, E.; Cammisotto, V.; Pasquale, C.; Crescioli, C.; et al. Gut-derived endotoxin stimulates factor VIII secretion from endothelial cells. Implications for hypercoagulability in cirrhosis. J. Hepatol. 2017, 67, 950-956. [CrossRef] [PubMed]

(C) 2018 by the authors. Licensee MDPI, Basel, Switzerland. This article is an open access article distributed under the terms and conditions of the Creative Commons Attribution (CC BY) license (http:/ / creativecommons.org/licenses/by/4.0/). 